\title{
Recurrent Home Flooding in Detroit, MI 2012-2020: Results of a Household Survey
}

\section{PETER S LARSON ( $\nabla$ anfangen@umich.edu )}

University of Michigan https://orcid.org/0000-0002-6621-7902

\section{Carina J Gronlund}

University of Michigan Institute for Social Research

Lyke Thompson

Wayne State University

Natalie Sampson

University of Michigan-Dearborn

Ramona Washington

Wayne State University

Jamie Steis Thorsby

Wayne State University

Natalie Lyon

Wayne State University

Carol Miller

Wayne State University

\section{Research}

Keywords: flooding, Detroit, environmental justice, climated change flooding, Detroit, environmental justice, climate change

Posted Date: May 5th, 2021

DOI: https://doi.org/10.21203/rs.3.rs-459157/v1

License: (c) (i) This work is licensed under a Creative Commons Attribution 4.0 International License.

Read Full License 


\section{Recurrent home flooding in Detroit, MI 2012-2020: Results of a household survey}

Peter S Larson ${ }^{1 *}$, Carina Gronlund ${ }^{2}$, Lyke Thompson ${ }^{4}$, Natalie Sampson ${ }^{3}$, Ramona Washington ${ }^{4}$, Jamie Steis Thorsby ${ }^{5}$, Natalie Lyon ${ }^{5}$ and Carol J Miller ${ }^{5}$

Author emails: Peter S. Larson: anfangen@umich.edu Carina Gronlund: gronlund@umich.edu Lyke Thompson: lyke@wayne.edu Natalie Sampson: nsampson@umich.edu Ramona Washington: as0293@wayne.edu Jamie Steis Thorsby: ab1421@wayne.edu Natalie Lyon: natalie.lyon@wayne.edu Carol Miller: ab1421@wayne.edu

\footnotetext{
${ }^{*}$ Correspondence:

anfangen@umich.edu

${ }^{1}$ Social Environment and Health, University of Michigan Institute for Social Research, Ann Arbor, USA Full list of author information is available at the end of the article
}

\begin{abstract}
Introduction: Household flooding has wide ranging social, economic and public health impacts particularly for people in resource poor communities. The determinants and outcomes of recurrent home flooding in urban contexts, however, are not well understood. A household survey was used to assess neighborhood and household level determinants of recurrent home flooding in Detroit, MI.
\end{abstract}

Methods: Survey activities covered the years of 2012 and 2020. Researchers collected information on past flooding, housing conditions, flooding outcomes and public health outcomes. Using the locations of homes and flooding occurrences, a "hot spot" analysis was performed to find areas of extreme risk within the City of Detroit. Survey data were linked to environment and neighborhood data and associations were tested using regression methods.

Results: 5,956 households participated in the survey and flooding information was available for 4,677 of them. Among these, 2,546 (42.75\%) reported having experienced home flooding as a result of rainfall. Rental occupied units were more likely to report flooding than owner occupied homes (OR $1.71[95 \% \mathrm{Cl} 1.5$, 1.94]). Housing conditions such as poor roof quality and cracks in basement walls influenced home flooding risk. Increased percentage of rental units in the vicinity of the home increased flooding risk. When controlling for household and neighborhood factors, primarily African American communities were found to be at high risk for home flooding. Flooding and conditions associated with home flooding were associated with adult and child asthma.

Conclusions: Recurrent home flooding is far more prevalent than previously thought and associated with neighborhood and household factors, in addition to disproportionately impacting African American residents. Programs that support recovery and which focus on home improvement to prevent flooding, particularly by landlords, might benefit the public health. These results draw awareness and urgency to problems of urban flooding and public health in other areas of the country confronting the compounding challenges of aging infrastructure, disinvestment and climate change.

Keywords: flooding; Detroit; environmental justice; climated change flooding, Detroit, environmental justice, climate change 


\section{Introduction}

Pluvial flooding and sewer overflows are a multifactorial public health problem that raise risks for mortality and morbidity of a host of serious conditions. Health impacts from flooding can be physical or psychological. Physical outcomes include gastrointestinal illnesses, respiratory illnesses, skin rashes and infections and poisoning from exposure to chemical irritants $[1,2,3,4,5,6,7]$. Psychological distress and trauma are common among people who have experienced sudden flooding as a result of extreme weather events $[8,9,10]$.

Flooding impacts different groups of people in distinct ways and impacts can be felt during or after the flooding event [11]. Women, the elderly and small children are more likely to experience physical and psychological outcomes during floods and men are at high risk for mortality during and after flooding events $[12,13,14,15,16]$. Intensity of flooding has a graded impact on physical and psychological health. Long term psychological effects such as anxiety, depression and PTSD can occur for several years following a flooding event $[17,18,8,19]$ and flooding can cause serious disruptions to the provisions of mental health treatment [20]. Long term effects include trauma and stress-related problems as a result of displacement, economic insecurity and future housing uncertainty [21]. Mortality has been found to increase in the months following major flood events [22] and flooding impacts can be felt even by persons outside flooded areas through groundwater contamination [23].

Climate and rainfall patterns in the Midwest region of the United States have been altered over the past five decades as a result of climate change [24, 25] and extreme flooding events have become more common in cities such as Detroit, MI during the past decade. Natural hazards and extreme weather events have become more common and increasingly costly in the US over the past two decades [26, 27 . Changes in frequency and intensity of rainfall patterns can overwhelm aging infrastructure in challenged cities like Detroit, and create multiple stormwater issues [28]. Globally, urban land exposed to climate and flooding hazard risks is expected to increase by more than 25 percent compared with current levels [29]. Increasing frequency of extreme weather events and inadequate and aging infrastructure are exacerbating flooding events [30] .

Home flooding is a serious public health problem that has long lasting economic and health impacts for people who experience it [31, 32, 33, 34, 35, 36, 37] . Natural hazards have been shown to exacerbate problems of economic inequality [38]. Serious impacts from flooding are the result of a confluence of factors including extreme weather events, robustness of infrastructure and other factors to mitigate flood risk, housing conditions and individual level vulnerability [39, 40]. Though significant effort has been directed to major flooding events (e.g. dam breaks, flood wave propagation), little work has been done on recurrent, localized pluvial and nonpluvial flooding in urban contexts.

The City of Detroit, MI, like many post-industrial cities, faces a wide range of converging challenges including population loss, demographic change and decades of financial and political neglect [41]. The City covers approximately $230 \mathrm{~km}^{2}$. As of 2020 , Detroit's population is $\sim 670,000$ people, down from a peak population of 1.6 million people in 1960 [42]. It is among the poorest of large cities in the US with a median household income of $\$ 31,000$, less than half of the state median income 
of $\$ 72,000$. Nearly 80 percent of Detroit residents are African-American [42]. The City struggles to provide public services to its residents as a result of declining tax revenues, low levels of investment and decline of population density which forces Detroit to provide services using antiquated systems appropriate for a much larger population [43].

Compounding these problems are broad issues including aging housing and public infrastructure and climate change, all of which combine to create conditions conducive to home flooding. A cross-sectional study of 164 homes in northwest Detroit indicated that $64 \%$ of homes experienced at least one flooding event in the past year, with many experiencing three or four events [44]. Researchers of a small qualitative study reported on interviews with residents across the city, confirming that flooding was widespread with many potential risk factors, resources for prevention and recovery were uneven, and social, economic, and mental and physical health implications were extensive [45]. The Detroit Office of Sustainability found that residents report that they experience flooding very often (13\%), somewhat often (23\%), and occasionally (32\%) [46]. Though extreme weather events such as that which caused major flooding in Detroit in 2014 have wide ranging acute impacts, recurrent household flooding may be an under-reported phenomenon in a city like Detroit and may be a problem that worsens with climate change [47].

Detroit's topography is mostly flat, with an overall change of only 33 meters between its highest and lowest points. The City's natural drainage is split between the Detroit and Rouge Rivers, though the natural tributaries were replaced with underground pipes prior to the 1960s. Water runoff and sewage flow through a combined system, discharging more than 58 million liters of treated and untreated sewage [48] which eventually flows into Lake Erie. A result of Detroit's combined system of rain runoff and sewage discharge is that large rain events can overwhelm the City's treatment system, causing sewage backflow into homes during storm weather events [49]. Communities along the Detroit River, most notably the Jefferson-Chalmers area, have historically experienced flooding events of various degrees. Aged housing stock, high prevalence of impervious surfaces and high prevalence of basements put Detroit residents at high risk for home flooding [50].

\subsection{Research goals}

Recurrent home flooding is an overlooked public health problem that presents a wide range of health risks to populations in economically challenged post-industrial cities like Detroit, Michigan. To inform prevention and recovery efforts, we first describe the extent and frequency of pluvial flooding in Detroit households using data from a house to house survey. As part of this effort, we seek to identify particular locations or areas at high risk for household flooding events. Next, we used location information to link households to other data sets to test for associations of household and neighborhood/tract level determinants of household flooding events. Using the results of the first two aims, we create a predictive model that could be used to predict flooding risk for individual households or households located within specific tracts or areas. Finally, we explore how flooding and factors associated with flooding might determine household asthma prevalence in surveyed households.

We hypothesize that flooding events are concentrated in specific areas and that households that experience flooding events are in proximity to other homes that 
experience flooding events. We test for associations of flooding with housing conditions, socio-economic factors and neighborhood characteristics. We expect that no one factor in isolation determines household level flooding risk and create a multivariate regression model to predict flood risk using all available variables. Finally, we test the hypothesis that home flooding and factors associated with home flooding also determine household level public health outcomes such as asthma, which may result from exposure to chemicals, bacteria, or mold.

\section{Methods}

\subsubsection{Survey of home flooding in Detroit}

Wayne State University's Center for Urban Studies (CUS) seeks to "improve understanding of and provide innovative responses to urban challenges and opportunities." As a part of its commitment to serving Detroit and its metropolitan area, the Center maintains a staff of professionals dedicated to identifying leverage opportunities to meet community need. In 2012, the Center created the Home Safety Assessment (HSA) as a joint effort between AmeriCorps, Wayne State University Center for Urban Studies, FEMA, Detroit Fire Department, Clear Corps, and the Kohl's Injury Prevention Program through the Children's Hospital of Michigan. The HSA is a risk assessment survey to determine if a resident's home has hazardous conditions such as asthma triggers, flood, and moisture/vapor intrusion and the vulnerability of the housing quality. Field staff conduct door-to-door canvasing dividing the zip codes in walkable target areas. Survey workers approached the home to determine if a household member was present. If no one was home at the time, workers returned at a later date, or scheduled visits on nights and weekends if necessary. To elicit residents' participation in the project the project offered a small, non-monetary incentives. Survey staff educated residents on ways to increase home safety, and referred residents to partner services available to them. Survey and community outreach activities are ongoing.

This research was deemed exempt from annual review by Institutional Review Boards at the University of Michigan (study number HUM00177793) and Wayne State University (study number 101619B3X).

\subsection{Neighborhood and environmental data}

Several other sources of data were leveraged for this study. As a proxy for neighborhood measure, census tract level measures of poverty and neighborhood age were obtained through the American Community Survey, a sample-based yearly survey of American households maintained by the United States Census [42]. Data for administrative boundaries and locations of waterways were obtained from the State of Michigan's GIS Portal [51]. One-meter elevation data was obtained from the Advanced Spaceborne Thermal Emission and Reflection Radiometer (ASTER) Digital Elevation Model from the National Aeronautics and Space Administration (NASA) [52]. Additional residential property information, or parcel data, were obtained from a database of public tax records from real estate analytics company CoreLogic [53]. This database consists of parcel-level property information collected from tax assessor's records as of 2016 and includes data on the year the structure was built, whether the unit is a rental unit or owner occupied, the assessed value of the home and whether the unit was a multifamily unit. 
Latitude and longitude for households were obtained with ArcMap ver 10.6.1 geocoder [54] using the home address listed in the CUS survey. Latitude and longitude coordinates that were outside of Detroit city limits were excluded from the analysis. Data from other layers such as elevation and neighborhood information were extracted using the latitude/longitude location of the household obtained from the geocoded address.

\subsubsection{Statistical methods}

Households were asked if their home had flooded in the past either as a result of rainfall or weather events. Using the data on past flooding, maps of household locations and flooding events were produced using the latitude and longitude coordinates of each home. "Hot" and "Cold" spots for household flooding were determined based on a Getis-Ord statistic at each point. The Getis-Ord Gi* statistic is produced by examining the value of each location in the context of all surrounding locations. Local sums are compared proportionally to the sum of all values surrounding it and z-scores and p-values are produced $[55,56]$. Areas of statistically high and low local risk are presented on a map to allow the identification of particular locations of interest. Hot and cold spots are defined as areas where there is statistical evidence that homes that experience/do not experience flooding are in close proximity to other homes that also experience/do not experience flooding.

Next, we tested for associations between households that experience flooding and those which did not using univariate logistic regression models. Significant associations were explored in more depth using locally-estimated scatterplot smoothing (LOESS) curves. Finally, backwards selection from a full model including all relevant and sufficiently represented predictors was used to construct a multivariate model of home flooding.

\section{Results}

3.0.1 Spatial distribution of flood risk in Detroit

Survey data from the Center for Urban Studies comprised 5,956 households between September 18, 2012 and May 5, 2020. Households were surveyed throughout the Detroit area. Data on the occurrence of flooding (self-reported) were available for 4,677 households. Among the surveyed households that responded to the question, $2546(42.75 \%)$ reported having experienced flooding as a result of rainfall.

Households that reported flooding were located throughout Detroit (see Figure 1 ) but hot spot analyses indicated that flooding incidence was not homogeneous throughout the city. Specifically, there were significant clusters of flooded homes in and around the Jefferson-Chalmers area. There were also significant clusters of homes that reported never having experienced flooding. See Figure 2.

\subsubsection{Household level correlates of home flooding}

In univariate analyses, we found that several factors were significantly associated with flooding risk among surveyed households. Rental homes were more likely to have experienced flooding than owner-occupied homes (OR 1.71 [95\% CI 1.5, 1.94]). Unfinished basements were associated with a higher odds of flooding than finished basements (OR 0.29 [95\% CI 1.06, 1.57]). 
Age of the home was initially found to be significant when comparing means of ages between homes that reported flooding vs. those that did not. However, we also explored whether patterns of flood risk might change over time in a non-linear manner. Figure 3 shows a locally estimated scatterplot smoothing (LOESS) based interpolation of flood risk as a function of the year of home construction. Risk for home flooding had a parabolic relationship to home age, with risk being the highest for the oldest homes, decreasing until $~ 1960$ and then rising again. See Figure 2. We then categorized the age of the home based on historical waves of home construction [57]. Compared with homes built before 1910, risk for flooding decreases for homes built in waves before 1958. Risk for flooding for home built in the late 20th century and early 21st century is similar to that of the oldest homes in Detroit. See Table 1 for full results.

Housing conditions were predictive of home flooding. Homes with roofs that were reported to be in good condition were found to be less likely to experience flooding (OR 0.59 [95\% CI 0.5, 0.68]). Homes with mold on the walls (OR 6.3 [95\% CI 5.39, 7.37]), moldy smells(OR 5.56 [95\% CI 4.8, 6.43]), basement in disrepair (OR 12.73 [95\% CI 10.44, 15.51]), uncapped sewer outlets (OR 2.2 [95\% CI 1.92, 2.51]) and occurrence of previous sewer backups (OR 17.86 [95\% CI 15.11, 21.1]) were found to be more prone to flooding. See Table 2 for full results.

\subsubsection{Neighborhood (census tract) and environmental correlates of home flooding}

Of interest to this research was how the surrounding environment raised or lowered the risk of home flooding. The following census tract characteristics were considered and found not to be significantly associated with flood risk: poverty, childhood poverty, percent African-American or Hispanic residents, percent of homes built before 1939, elevation and the distance to the nearest waterway. However, percentage of all homes in the census tract that are owner-occupied was inversely associated with flood risk (OR 0.89 [95\% CI 0.84, 0.94]). See Table 3 for full results.

\subsubsection{Multivariable model of home flooding}

We tested associations of all variables with home flooding in a multivariate model. Missing data was a problem for many available variables. Any variable with more than $10 \%$ of observations missing was excluded from the analysis. Multiple imputation was used to fill in the missing values for the remaining set of predictors [58] so that we could create a "full model" of household and neighborhood factors on home flooding. Using this model, we used a backward selection procedure to successively delete variables based on significance until a final, optimal model based on Akaike's Information Criterion (AIC) [59] was obtained. Variables that were sufficiently represented in the data set to allow model inclusion comprised all census tract level variables such as poverty, racial composition, age of homes in the area, elevation and distance to nearest waterway. Rent/own status and variables on various aspects of housing condition such as leaks and cracks in basement and outer walls were also retained.

After model selection, only a handful of variables were dropped including census tract level poverty and childhood poverty, distance to nearest waterway, elevation and chimney leaks. In the multivariate model we found that the percentage of the 
census tract that is African-American was associated with home flooding (OR 1.14 95\% CI $[1.04,1.25]$.) Rental status (OR 1.43 95\% CI $[1.19,1.67]$ ) and neighborhood level home ownership (OR .90 95\% CI $[.83, .97]$ ) were also found to be associated with water entering the home. Almost all of the variables on home leaks remained in the model even though though roof leaks and chimney leaks were dropped from the final model. Sewer backups were left in the model building process as a proxy for the relative quality of the surrounding sewer and flooding infrastructure. Even when controlling for other factors, the odds of flooding given sewer leaks were very high (OR 11.9 95\% CI $[9.82,14.07])$. We note that not all homes that experienced flooding experienced sewer backups and not all homes that reported sewer backups reported rain associated flooding. See Table 4 for full results.

\subsubsection{Asthma and home flooding}

A total of 4,546 residents reported having at least one person in the home who had a diagnosis of asthma from a health care professional. 5,140 residents reported having at least one child in the home with asthma. Having at least one person with asthma in the home was associated with flooding ((OR $1.3[95 \%$ CI 1.14, 1.49])). Adults with asthma were also very likely to live with a child with asthma (OR 1.3 [95\% CI 1.1, 1.55]). Nearly all of the household and neighborhood variables were associated with asthma cases with only the exception of the age of the home, roof leaks, chimney leaks and proper sink and bathtub drainage. Other possible predictors of asthma cases such as having a smoker in the home and household breathing problems were also available in the data set and were included in Table 5 .

\section{Discussion}

Using a house-to-house survey of homes and residents throughout the city, we have shown that regular home flooding is a serious problem that impacts Detroit residents. We also found that though people all over Detroit experience home flooding, certain areas are at particular risk for basement and home flooding events. We found that renters and those living in areas where most residents are renters live at particular risk for flooding. We found that poor housing conditions directly impact risk for flooding. When controlling for housing and neighborhood factors, we found that flooding disproportionately impacts communities of color. Finally, we found that flooding is associated with asthma risk in both adults and children.

Our results suggest that home flooding is a far more serious issue than previously thought, disproportionately impacting people who may lack financial means to effectively recover from flooding events and pluvial disasters, and who, due their status as renters, may lack the ability to implement measures to prevent or to mitigate the impacts of floods, such as basement weatherization or roof repairs. This would suggest that a focus on home flooding risk and efforts to improve housing quality should be a priority not only for advocates of urban housing, but also for public health organizations, focusing on programs that educate, work with, and provide resources to renters and incentives to landlords to improve housing quality/maintenance. Research in Germany has also suggested that directly communicating risks of flooding to home owners might encourage them to make improvements to prevent or mitigate flooding risk [60]. Direct communication to landlords, for example, might encourage some to make necessary repairs and improvements to their properties. 
The biggest limitation of this study was the measure of the flooding outcome. Reporting of flooding occurred only during the in-home visit by the survey team. Thus, flooding events long before the visit that were not in the recollection of the home occupant, and/or flood events after the survey visit were not recorded. Many homes that did not report flooding were visited prior to the city-wide flood of 2014 with the result that impacts from that event were not recorded for those households. Thus, the outcome measurement should be considered an underestimate. Compliance with survey projects is always a challenge. In the case of this study, certain biases should be assumed. For example, given that the present study was described as pertaining to housing conditions and flooding, we might assume that occupants of homes might be more likely to respond who experienced flooding or whose homes were in poor condition.

The flooding data collected also was not specific enough to make recommendations for specific interventions regarding household level flood mitigation. There are multiple causes of in-home flooding, including: sewer back-up, rising water levels of nearby waterways, ponded water around the home, rising groundwater levels around the home and subsequent leakage through foundation and basement, direct inflow through roof leaks, leaks of interior piping, and others. In many cases the flooding may stem from a variety of causes and problems. Future research efforts might ask residents to report incidence of recurrent home flooding to researchers or community leaders and teams could be dispatched to collect detailed information on sources and outcomes.

Detroit experiences the highest health impacts of asthma in Michigan, with the adult asthma rate $29 \%$ higher and the rate of asthma-related hospitalizations three times greater than the state average [61]. In-home triggers account for $40 \%$ of all asthma episodes [62]. Detroit has been called the "Epicenter of the Asthma Burden," with at least $11.3 \%$ of Detroit children and $15.5 \%$ of Detroit adults having diagnosed asthma [63]. Future studies of this kind could focus on the public health impacts of recurrent flooding in households and how home improvement measures can be implemented as a means of reducing risk for serious health problems. Using a crude measurement of asthma prevalence, our research suggested that housing quality and flooding risk were associated with asthma in both adults and children. Future research should work to better characterize the public health impacts of regular flooding by implementing programs that improve housing conditions, such as basic measures to prevent basement leakage, while looking at basic health indicators.

Future survey work should attempt to validate the results of this research and be designed to better understand the causes and outcomes of regular flooding in Detroit. Survey efforts should be conducted on a regular basis, but should also mobilize during or after times of intense precipitation or known flooding events. Any survey work should allow the collection of quantitative data such as high water mark and source location, but should also collect detailed information on individual, home and neighborhood conditions that might contribute to flooding. Qualitative information on residents' experiences and ideas could help inform community and government efforts to mitigate flood and support flood victims. The often overlooked public health implications of regular flooding should, however, be a major focus of future research work to ensure equitable prevention and response. 


\section{Conclusions}

Pluvial household flooding is a serious problem for Detroit residents though risk is clustered in certain areas of the city. People living in rental units experience higher risks for household flooding than those in owner occupied units and poor housing conditions are predictive of water entering the home. When controlling for other factors, African American communities were found to be at higher risk for floods than other communities. Finally, we found that flooding is associated with public health outcomes such as asthma. We conclude that flooding in Detroit is an important environmental justice and public health issue worthy of further attention to researchers and public policy advocates.

\section{Acknowledgements}

This work was supported by the Healthy Urban Waters program at Wayne State University, funded by the Erb Family Foundation. This work was also supported by grant R00ES026198 (CJG) from the National Institute of Environmental Health Sciences and a postdoctoral research fellowship (PL) from the University of Michigan Institute for Global Change Biology.

\section{Declarations}

Competing interests

The authors declare that they have no competing interests.

Availability of data and materials

Data and materials are available upon request.

Author's contributions

All authors contributed to the writing of the manuscript. LT, CM, RW, JS, JL participated in the original survey design and data collection. PL performed statistical analyses and wrote the initial draft of the manuscript.

Funding

This research was funded by Joint Usage/Research Center on Tropical Disease, Institute of Tropical Medicine (NEKKEN),Nagasaki University, Japan and the Nagasaki School of Tropical Medicine and Global Health, Japan.

Consent to publish

All authors consent to have this work published.

Ethical approval

Ethical approval was given by The Ethical Review Committee of the School of Tropical Medicine and Global Health at Nagasaki University (No.24). Additionally, the Public Research Program and Center at KEMRI approved this research under the ongoing project "Health and Demographic Surveillance Systems in Kwale," SSC No. 1088. It has also been approved by The Scientific and Ethical Committees of Kenya Medical Research Institute and the Institutional Review Board of the Institute of Tropical Medicine, Nagasaki University (IRB \# 06060604) since 18 Oct 2016. 
Author details

${ }^{1}$ Social Environment and Health, University of Michigan Institute for Social Research, Ann Arbor, USA. ${ }^{2}$ University of Michigan Institute for Social Survey Research Center Social Environment and Health Program, Ann Arbor, MI, USA. ${ }^{3}$ University of Michigan-Dearborn, Dearborn, MI, USA. ${ }^{4}$ Center for Urban Studies, Wayne State University, Detroit, MI, USA. ${ }^{5}$ Healthy Urban Waters, Wayne State University, Detroit, MI, USA.

References

1. Mulder, A.C., Pijnacker, R., De Man, H., Van De Kassteele, J., Van Pelt, W., Mughini-Gras, L., Franz, E.: "sickenin' in the rain" - increased risk of gastrointestinal and respiratory infections after urban pluvial flooding in a population-based cross-sectional study in the netherlands. BMC Infectious Diseases 19(1) (2019). doi:10.1186/s12879-019-3984-5

2. Wade, T.J., Lin, C.J., Jagai, J.S., Hilborn, E.D.: Flooding and emergency room visits for gastrointestinal illness in massachusetts: A case-crossover study. PLOS ONE 9(10), 110474 (2014). doi:10.1371/journal.pone.0110474

3. Jagai, J.S., Deflorio-Barker, S., Lin, C.J., Hilborn, E.D., Wade, T.J.: Sanitary sewer overflows and emergency room visits for gastrointestinal illness: Analysis of massachusetts data, 2006-2007. Environmental Health Perspectives 125(11), 117007 (2017). doi:10.1289/ehp2048

4. De Man, H., Mughini Gras, L., Schimmer, B., Friesema, I.H.M., De Roda Husman, A.M., Van Pelt, W.: Gastrointestinal, influenza-like illness and dermatological complaints following exposure to floodwater: a cross-sectional survey in the netherlands. Epidemiology and Infection 144(7), 1445-1454 (2016). doi:10.1017/s0950268815002654

5. Oluyomi, A.O., Panthagani, K., Sotelo, J., Gu, X., Armstrong, G., Luo, D.N., Hoffman, K.L., Rohlman, D., Tidwell, L., Hamilton, W.J., et al.: Houston hurricane harvey health (houston-3h) study: assessment of allergic symptoms and stress after hurricane harvey flooding. Environmental Health 20(1) (2021). doi:10.1186/s12940-021-00694-2

6. Flores, A.B., Castor, A., Grineski, S.E., Collins, T.W., Mullen, C.: Petrochemical releases disproportionately affected socially vulnerable populations along the texas gulf coast after hurricane harvey. Population and Environment 42(3), 279-301 (2021). doi:10.1007/s11111-020-00362-6

7. Anenberg, S.C., Kalman, C.: Extreme weather, chemical facilities, and vulnerable communities in the u.s. gulf coast: A disastrous combination. GeoHealth 3(5), 122-126 (2019). doi:10.1029/2019gh000197

8. Greene, G., Paranjothy, S., Palmer, S.R.: Resilience and vulnerability to the psychological harm from flooding: The role of social cohesion. American Journal of Public Health 105(9), 1792-1795 (2015). doi:10.2105/ajph.2015.302709

9. Lamond, J.E., Joseph, R.D., Proverbs, D.G.: An exploration of factors affecting the long term psychological impact and deterioration of mental health in flooded households. Environmental Research 140, 325-334 (2015) doi:10.1016/j.envres.2015.04.008

10. Mason, V., Andrews, H., Upton, D.: The psychological impact of exposure to floods. Psychology, Health and Medicine 15(1), 61-73 (2010). doi:10.1080/13548500903483478

11. Lowe, D., Ebi, K.L., Forsberg, B.: Factors increasing vulnerability to health effects before, during and after floods. International Journal of Environmental Research and Public Health 10(12), 7015-7067. doi:10.3390/ijerph10127015

12. Haynes, K., Coates, L., van den Honert, R., Gissing, A., Bird, D., Dimer de Oliveira, F., D'Arcy, R., Smith, C. Radford, D.: Exploring the circumstances surrounding flood fatalities in australia-1900-2015 and the implications for policy and practice. Environmental Science and Policy 76, 165-176 (2017). doi:10.1016/j.envsci.2017.07.003

13. Ashley, S.T., Ashley, W.S.: Flood fatalities in the united states. Journal of Applied Meteorology and Climatology 47(3), 805-818 (2008). doi:10.1175/2007jamc1611.1

14. Salvati, P., Petrucci, O., Rossi, M., Bianchi, C., Pasqua, A.A., Guzzetti, F.: Gender, age and circumstances analysis of flood and landslide fatalities in italy. Science of The Total Environment 610-611, 867-879 (2018) doi:10.1016/j.scitotenv.2017.08.064

15. Jonkman, S.N., Kelman, I.: An analysis of the causes and circumstances of flood disaster deaths. Disasters 29(1), 75-97 (2005). doi:10.1111/j.0361-3666.2005.00275.x

16. Pereira, S., Diakakis, M., Deligiannakis, G., Zêzere, J.L.: Comparing flood mortality in portugal and greece (western and eastern mediterranean). International Journal of Disaster Risk Reduction 22, 147-157 (2017) doi:10.1016/j.ijdrr.2017.03.007

17. Jermacane, D., Waite, T.D., Beck, C.R., Bone, A., Amlôt, R., Reacher, M., Kovats, S., Armstrong, B., Leonardi, G., Rubin, G.J., Oliver, I.: The english national cohort study of flooding and health: The change in the prevalence of psychological morbidity at year two. BMC Public Health 18 (2018). doi:10.1186/s12889-018-5236-9

18. Mulchandani, R., Armstrong, B., Beck, C.R., Waite, T.D., Amlôt, R., Kovats, S., Leonardi, G., Rubin, G.J., Oliver, I.: The english national cohort study of flooding and health: Psychological morbidity at three years of follow up. BMC Public Health 20, 1-7 (2020)

19. Gray, S.: Long-term health effects of flooding. Journal of Public Health 30(4), 353-354 (2008). doi:10.1093/pubmed/fdn092

20. Wang, P.S., Gruber, M.J., Powers, R.E., Schoenbaum, M., Speier, A.H., Wells, K.B., Kessler, R.C.: Disruption of existing mental health treatments and failure to initiate new treatment after hurricane katrina. The American Journal of Psychiatry 165(1), 34-41 (2008). doi:10.1176/appi.ajp.2007.07030502

21. Zhong, S., Yang, L., Toloo, S., Wang, Z., Tong, S., Sun, X., Crompton, D., Fitzgerald, G., Huang, C.: The long-term physical and psychological health impacts of flooding: A systematic mapping. Science of The Total Environment 626, 165-194 (2018). doi:10.1016/j.scitotenv.2018.01.041

22. Stephens, K.U., Grew, D., Chin, K., Kadetz, P., Greenough, P.G., Burkle, F.M., Robinson, S.L., Franklin, E.R. Excess mortality in the aftermath of hurricane katrina: A preliminary report. Disaster Medicine and Public Health Preparedness 1(1), 15-20 (2007). doi:10.1097/dmp.0b013e3180691856 
23. Andrade, L., O'Dwyer, J., O'Neill, E., Hynds, P.D.: Surface water flooding, groundwater contamination, and enteric disease in developed countries: A scoping review of connections and consequences. Environmental Pollution 236, 540-549 (2018). doi:10.1016/j.envpol.2018.01.104

24. Angel, J., Swanston, C., Mayes Boustead, B., Conlon, K.C., Hall, K.R., Jorns, J.L., Kunkel, K.E., Lemos, M.C. Lofgren, B., Ontl, T.A., Posey, J., Stone, K., Takle, E., Todey, D.: Impacts, risks, and adaptation in the united states: Fourth national climate assessment chapter 21: Midwest. U.S. Global Change Research Program, 872-940 (2018). doi:10.7930/NCA4.2018.CH21

25. Dai, S., Shulski, M.D., Hubbard, K.G., Takle, E.S.: A spatiotemporal analysis of midwest us temperature and precipitation trends during the growing season from 1980 to 2013. International Journal of Climatology 36(1), 517-525 (2016). doi: $10.1002 /$ joc. 4354

26. Limaye, V.S., Max, W., Constible, J., Knowlton, K.: Estimating the health-related costs of 10 climate-sensitive u.s. events during 2012. GeoHealth 3(9), 245-265 (2019). doi:10.1029/2019gh000202

27. Hsiang, S., Kopp, R., Jina, A., Rising, J., Delgado, M., Mohan, S., Rasmussen, D.J., Muir-Wood, R., Wilson, P., Oppenheimer, M., Larsen, K., Houser, T.: Estimating economic damage from climate change in the united states. Science 356(6345), 1362-1369 (2017). doi:10.1126/science.aal4369

28. Sandink, D.: Urban flooding and ground-related homes in canada: an overview. Journal of Flood Risk Management 9(3), 208-223 (2016). doi:10.1111/jfr3.12168

29. Guneralp, B., Guneralp, I., Liu, Y.: Changing global patterns of urban exposure to flood and drought hazards. Global Environmental Change 31, 217-225 (2015). doi:10.1016/j.gloenvcha.2015.01.002

30. Melillo, J.M., Richmond, T.T.C.., Yohe, G.W.: Climate change impacts in the united states: The third national climate assessment. U.S. Global Change Research Program (2014). doi:10.7930/J0Z31WJ2

31. Woodhall-Melnik, J., Grogan, C.: Perceptions of mental health and wellbeing following residential displacement and damage from the 2018 st. john river flood. International Journal of Environmental Research and Public Health 16(21), 4174 (2019). doi:10.3390/ijerph16214174

32. Poole, J.A., Barnes, C.S., Demain, J.G., Bernstein, J.A., Padukudru, M.A., Sheehan, W.J., Fogelbach, G.G., Wedner, J., Codina, R., Levetin, E., Cohn, J.R., Kagen, S., Portnoy, J.M., Nel, A.E.: Impact of weather and climate change with indoor and outdoor air quality in asthma: A work group report of the aaaai environmental exposure and respiratory health committee. Journal of Allergy and Clinical Immunology 143(5), 1702-1710 (2019). doi:10.1016/j.jaci.2019.02.018

33. Phillippi, S.W., Beiter, K., Thomas, C.L., Sugarman, O.K., Wennerstrom, A., Wells, K.B., Trapido, E.: Medicaid utilization before and after a natural disaster in the 2016 baton rouge-area flood. American Journal of Public Health 109(S4), 316-321 (2019). doi:10.2105/ajph.2019.305193

34. Lal, A., Fearnley, E., Wilford, E.: Local weather, flooding history and childhood diarrhoea caused by the parasite cryptosporidium spp.: A systematic review and meta-analysis. Science of The Total Environment 674, 300-306 (2019). doi:10.1016/j.scitotenv.2019.02.365

35. Demain, J.G.: Climate change and the impact on respiratory and allergic disease: 2018. Current Allergy and Asthma Reports 18(4) (2018). doi:10.1007/s11882-018-0777-7

36. Graham, H., White, P., Cotton, J., McManus, S.: Flood- and weather-damaged homes and mental health: An analysis using england's mental health survey. International Journal of Environmental Research and Public Health 16(18), 3256 (2019). doi:10.3390/ijerph16183256

37. Rorie, A., Poole, J.A.: The role of extreme weather and climate-related events on asthma outcomes. Immunology and allergy clinics of North America 41(1), 73-84 (2021). doi:10.1016/j.iac.2020.09.009

38. Howell, J., Elliott, J.R.: Damages done: The longitudinal impacts of natural hazards on wealth inequality in the united states. Social Problems 66(3), 448-467. doi:10.1093/socpro/spy016

39. Depietri, Y., McPhearson, T.: Changing urban risk: 140 years of climatic hazards in new york city. Climatic Change 148(1-2), 95-108 (2018). doi:10.1007/s10584-018-2194-2

40. Field, C.B., Barros, V., Stocker, T.F., Dahe, Q., Dokken, D.J., Ebi, K.L., Mastrandrea, M.D., Mach, K.J., Plattner, G.-K., Allen, S.K., Tignor, M., Midgley, P.M.: Managing the risks of extreme events and disasters to advance climate change adaptation: Special report of the intergovernmental panel on climate change (2012). doi:10.1017/CBO9781139177245

41. Sugrue, T.J.: The origins of the urban crisis: Race and inequality in postwar detroit race and inequality in postwar detroit (2014)

42. United States Census Bureau: 2015-2019 american community survey (acs) 5-year public use microdata sample (pums) (2020)

43. Dewar, M., Thomas, J.M.: The City After Abandonment vol. 13. University of Pennsylvania Press, Philadelphia, Pennsylvania (2013)

44. Nassauer, J., Dewar, M., McElmurry, S., Sampson, N., Alvarez, A., Burton, A., Riseng, C., Schulz, A., Webster, N., Lichten, N.: New-gi: Neighborhood, environment and water research collaborations for green infrastructure. (2016)

45. Sampson, N.R., Price, C.E., Kassem, J., Doan, J., Hussein, J.: "we're just sitting ducks": Recurrent household flooding as an underreported environmental health threat in detroit's changing climate. International Journal of Environmental Research and Public Health 16(1), 6 (2019). doi:10.3390/ijerph16010006

46. Office of Sustainability: The Sustainability Action Agenda: Summary survey results [presentation]. City of Detroit (2019). https:

//detroitmi.gov/government/mayors-office/office-sustainability/sustainability-action-agenda

47. Festing, H., Copp, C., Sprague, H., Wolf, D., Shorofsky, B., Nichols, K.: The prevalence and cost of urban flooding: A case study of Cook County, IL. The Center for Neighborhood Technology, Chicago, IL, USA (2014). https://www.cnt.org/publications/the-prevalence-and-cost-of-urban-flooding

48. Michigan Department of Environment, Great Lakes, and Energy: Combined sewer overflow (CSO), sanitary sewer overflow (SSO), and retention treatment basin (RTB) discharge 2018 annual report. State of Michigan (2018). https://www.mi.gov/sewagedischarge

49. Steis Thorsby, J., Miller, C.J., Treemore-Spears, L.: The role of green stormwater infrastructure in flood 
mitigation (detroit, mi usa) - case study. Urban Water Journal 17(9), 838-846 (2020) doi:10.1080/1573062X.2020.1823429

50. Sampson, N., Hill Knott, K., Smith, D., Mekias, L., Howrani Heeres, J., Sagovac, S.: Planning for climate change in legacy cities: The case of detroit, michigan. Michigan Journal of Sustainability 2 (2014). doi:10.3998/mjs.12333712.0002.004

51. State of Michigan: GIS Open Data. State of Michigan GIS Portal, Lansing, MI USA (2021). https://gis-michigan.opendata.arcgis.com/

52. NASA METI AIST Japan Spacesystems and U.S./Japan ASTER Science Team: ASTER DEM Product. NASA EOSDIS Land Processes DAAC (2021). doi:10.5067/ASTER/AST14DEM.003. https://doi.org/10.5067/ASTER/AST14DEM. 003

53. CoreLogic: CoreLogic parcel level real estate data. CoreLogic tax records. https://apps.lib.umich.edu/database/link/43987

54. Environmental Systems Research Institute: ArcGIS Desktop, Redlands, CA (2011)

55. Getis, A., Ord, J.K.: The analysis of spatial association by use of distance statistics. Geographical Analysis 24(3), 189-206 (1992). doi:10.1111/j.1538-4632.1992.tb00261.x

56. Ord, J.K., Getis, A.: Local spatial autocorrelation statistics: Distributional issues and an application. Geographical Analysis 27(4), 286-306 (1995). doi:10.1111/j.1538-4632.1995.tb00912.x

57. Schuster, S.: Boom and bust: Detroit's housing construction trends (2018)

58. van Buuren, S., Groothuis-Oudshoorn, K.: Mice: Multivariate imputation by chained equations in $r$. Journal of Statistical Software 45(3), 1-67 (2011). doi:10.18637/jss.v045.i03

59. Akaike, H.: Likelihood of a model and information criteria. Journal of Econometrics 16(1), 3-14 (1981). doi:10.1016/0304-4076(81)90071-3

60. Grothmann, T., Reusswig, F.: People at risk of flooding: Why some residents take precautionary action while others do not. Natural Hazards 38(1-2), 101-120 (2006). doi:10.1007/s11069-005-8604-6

61. DeGuire, P., Cao, B., Wisnieski, L., Strane, D., Wahl, R., Lyon-Callo, S., Garcia, E.: Detroit: The current status of the asthma burden. Michigan Department of Health and Human Services, Bureau of Disease Control, Prevention and Epidemiology (2016). http://169.62.82.226/documents/mdhhs/Detroit-AsthmaBurden_516668_7.pdf

62. Gautier, C., Charpin, D.: Environmental triggers and avoidance in the management of asthma. Journal of Asthma and Allergy 10, 47-56 (2017). doi:10.2147/jaa.s121276

63. Childhood Lead Poisoning Prevention Program, Division of Environmental Health: Childhood lead poisoning prevention in Michigan, fiscal year 2017 report to the legislature. Michigan Department of Health and Human Services (2018). https:

//www.michigan.gov/documents/lead/FY_2017_CLPPP_LEGISLATIVE_REPORT_November_2018_647060_7.pdf

\section{Figures}

Figure 1 Locations of households which reported that they experienced pluvial flooding. Households that responded that no flooding occurred are not shown.

Figure 2 Hot and cold spots of flooding using the Getis-Ord Gi* statistic. Red dots represent "hot" spots, or locations of statistically significant clusters of homes that experienced flooding. Blue does represent clusters of homes that reported not experiencing flooding.

Figure 3 Estimated flooding risk by year of construction using LOESS interpolation method. Vertical lines represent successive building waves $(1870-1910,1911-1930$, etc.) used to create housing construction categories. 


\section{Tables}

\section{List of Figures}

1 Locations of households which reported that they experienced pluvial flooding. Households that responded that no flooding occurred are not shown. . . . . . . . . . . . . . . . . 12

2 Hot and cold spots of flooding using the Getis-Ord Gi* statistic. Red dots represent "hot" spots, or locations of statistically significant clusters of homes that experienced flooding. Blue does represent clusters of homes that reported not experiencing flooding. . . . . . . . . . . . . . . 12

3 Estimated flooding risk by year of construction using LOESS interpolation method. Vertical lines represent successive building waves (1870 - 1910, 1911 - 1930, etc.) used to create housing construction categories. . . . . . . . . . . . . 12

\section{List of Tables}

1 Comparison of household factors by flooding status. Counts and percentages of categorical predictors are noted. Continuous variables are shown as means with standard deviation in parentheses. Comparisons of flooding with categorical predictors are made using Chisquare tests. Comparisons of flooding for continuous predictors are made using t-tests of means. Odds ratios for continuous predictors are based on standardized values (z-scores). presented for categorical predictors. Both continuous and categorical forms of the year the house was built are presented. . . . . . . . . . . . . . . 14

2 Housing conditions and flooding. Housing condition measurements were self reported by residents and confirmed by survey workers where possible. . . . . . . . . . . . . . . . . . . . 15

3 Neighborhood and environmental determinants of recurrent home flooding. Odds ratios for continuous measures produced using standardized values (z-scores). . . . . . . . . . . . . . 16

$4 \quad$ Full and reduced models of flooding using all sufficiently represented variables. Reduced model found through backwards selection through AIC. All continuous variables have been standardized and thus odds ratios for these variables represent changes in odds given unit changes in z-scores. . . . . . . . . . . . . . . . . . . . . 17

5 Prevalence and determinants of asthma in at least one adult member of the household. Odds ratios for continuous measures from standardized values (z-scores). . . . . . . . . . . . . . 
Table 1: Comparison of household factors by flooding status. Counts and percentages of categorical predictors are noted. Continuous variables are shown as means with standard deviation in parentheses. Comparisons of flooding with categorical predictors are made using Chi-square tests. Comparisons of flooding for continuous predictors are made using t-tests of means. Odds ratios for continuous predictors are based on standardized values (z-scores). presented for categorical predictors. Both continuous and categorical forms of the year the house was built are presented.

\begin{tabular}{|c|c|c|c|c|c|}
\hline & $\begin{array}{c}{[\mathrm{ALL}]} \\
\mathrm{N}=4489\end{array}$ & $\begin{array}{l}\text { No flood } \\
\mathrm{N}=2065\end{array}$ & $\begin{array}{c}\text { Flood } \\
\mathrm{N}=2424\end{array}$ & OR & p.ratio \\
\hline \multicolumn{6}{|l|}{ Own or rent home: } \\
\hline Own & $2992(66.7 \%)$ & $1507(73.0 \%)$ & $1485(61.3 \%)$ & Ref. & Ref. \\
\hline Rent & $1497(33.3 \%)$ & $558(27.0 \%)$ & $939(38.7 \%)$ & $1.71[1.50 ; 1.94]$ & 0.000 \\
\hline \multicolumn{6}{|c|}{ Year house was built (categorical): } \\
\hline Pre 1910 & $858(25.1 \%)$ & $298(18.4 \%)$ & $560(31.1 \%)$ & Ref. & Ref. \\
\hline $1910-1930$ & $1218(35.6 \%)$ & $595(36.7 \%)$ & $623(34.6 \%)$ & $0.56[0.47 ; 0.67]$ & ¡0.001 \\
\hline $1931-1940$ & $387(11.3 \%)$ & $237(14.6 \%)$ & $150(8.32 \%)$ & $0.34[0.26 ; 0.43]$ & 0.000 \\
\hline 1941-1945 & $97(2.83 \%)$ & $51(3.14 \%)$ & $46(2.55 \%)$ & $0.48[0.31 ; 0.73]$ & 0.001 \\
\hline $1946-1957$ & $641(18.7 \%)$ & $351(21.6 \%)$ & $290(16.1 \%)$ & $0.44[0.36 ; 0.54]$ & ¡0.001 \\
\hline 1958 or later & $224(6.54 \%)$ & $90(5.55 \%)$ & $134(7.43 \%)$ & $0.79[0.59 ; 1.07]$ & 0.133 \\
\hline Building sq ft & $1371(717)$ & $1345(676)$ & $1394(752)$ & $1.07[1.00 ; 1.14]^{*}$ & 0.035 \\
\hline Living space sq ft & $1368(711)$ & $1344(676)$ & $1390(740)$ & $1.07[1.00 ; 1.14]^{*}$ & 0.047 \\
\hline Basement sq ft & $817(278)$ & $803(259)$ & $831(294)$ & $1.11[1.04 ; 1.18]^{*}$ & 0.002 \\
\hline \multicolumn{6}{|l|}{ Type of basement: } \\
\hline Finished & $457(11.8 \%)$ & $243(13.2 \%)$ & $214(10.5 \%)$ & Ref. & Ref. \\
\hline Unfinished & $3427(88.2 \%)$ & $1603(86.8 \%)$ & $1824(89.5 \%)$ & $1.29[1.06 ; 1.57]$ & 0.010 \\
\hline
\end{tabular}

* Odds ratio from standardized values (z-scores) of continuous measure. 
Table 2: Housing conditions and flooding. Housing condition measurements were self reported by residents and confirmed by survey workers where possible.

\begin{tabular}{|c|c|c|c|c|c|}
\hline & $\begin{array}{c}{[\mathrm{ALL}]} \\
\mathrm{N}=4617\end{array}$ & $\begin{array}{l}\text { No flood } \\
N=2097\end{array}$ & $\begin{array}{c}\text { Flood } \\
\mathrm{N}=2520\end{array}$ & OR & $\mathrm{p}$ \\
\hline Roof in good condition & $861(23.6 \%)$ & $477(28.9 \%)$ & $384(19.2 \%)$ & $0.59[0.50 ; 0.68]$ & ¡0.001 \\
\hline Mold on walls of basement & $3319(74.4 \%)$ & $1181(57.1 \%)$ & $2138(89.3 \%)$ & $6.30[5.39 ; 7.38]$ & 0.000 \\
\hline Moldy smells & $3219(71.9 \%)$ & $1128(54.4 \%)$ & $2091(86.9 \%)$ & $5.55[4.80 ; 6.44]$ & 0.000 \\
\hline Basement needs repair & $3215(75.5 \%)$ & $1149(55.7 \%)$ & $2066(94.1 \%)$ & $12.7[10.5 ; 15.5]$ & 0.000 \\
\hline Roof leaks & $3610(85.6 \%)$ & $1565(81.2 \%)$ & $2045(89.4 \%)$ & $1.95[1.63 ; 2.32]$ & $¡ 0.001$ \\
\hline Window leaks & $3934(93.3 \%)$ & $1762(91.4 \%)$ & $2172(94.9 \%)$ & $1.75[1.37 ; 2.24]$ & $¡ 0.001$ \\
\hline Chimney leaks & $4113(97.6 \%)$ & $1864(96.7 \%)$ & $2249(98.3 \%)$ & $1.95[1.30 ; 2.94]$ & 0.001 \\
\hline Plumbing leaks & $3805(90.3 \%)$ & $1638(85.0 \%)$ & $2167(94.7 \%)$ & $3.16[2.54 ; 3.95]$ & 0.000 \\
\hline No leaks & $1333(31.6 \%)$ & $810(42.0 \%)$ & $523(22.9 \%)$ & $0.41[0.36 ; 0.47]$ & 0.000 \\
\hline Foundation cracks & $3567(84.6 \%)$ & $1493(77.5 \%)$ & $2074(90.6 \%)$ & $2.82[2.36 ; 3.36]$ & 0.000 \\
\hline Sinks and bathtub drain properly & $1286(27.9 \%)$ & $684(32.6 \%)$ & $602(23.9 \%)$ & $0.65[0.57 ; 0.74]$ & ¡0.001 \\
\hline Uncapped sewer outlets & $3101(71.2 \%)$ & $1257(62.6 \%)$ & $1844(78.6 \%)$ & $2.20[1.92 ; 2.51]$ & 0.000 \\
\hline Ever had sewer backups & $3028(66.8 \%)$ & $775(37.4 \%)$ & $2253(91.4 \%)$ & $17.8[15.1 ; 21.1]$ & 0.000 \\
\hline
\end{tabular}


Table 3: Neighborhood and environmental determinants of recurrent home flooding. Odds ratios for continuous measures produced using standardized values (z-scores).

\begin{tabular}{lccccc}
\hline & {$[$ ALL $]$} & No flood & Flood & OR & p.ratio \\
& $\mathrm{N}=4677$ & $\mathrm{~N}=2131$ & $\mathrm{~N}=2546$ & & \\
Census tract poverty (\%) & $43.8(11.5)$ & $43.7(11.4)$ & $43.9(11.6)$ & $1.02[0.96 ; 1.08]^{*}$ & 0.586 \\
Census tract under 18 poverty (\%) & $60.6(17.4)$ & $60.5(17.4)$ & $60.6(17.4)$ & $1.01[0.95 ; 1.07]^{*}$ & 0.717 \\
African-American population (\%) & $85.1(24.9)$ & $84.8(24.8)$ & $85.4(25.0)$ & $1.03[0.96 ; 1.11]$ & 0.376 \\
Hispanic population (\%) & $8.02(19.5)$ & $7.87(19.1)$ & $8.15(19.9)$ & $1.02[0.94 ; 1.10]$ & 0.648 \\
Percent of homes owner occupied & $50.9(13.7)$ & $51.8(12.7)$ & $50.2(14.4)$ & $0.89[0.84 ; 0.94]$ & $¡ 0.001$ \\
Percent of homes built before 1939 & $41.1(24.6)$ & $40.4(24.6)$ & $41.6(24.6)$ & $1.05[0.99 ; 1.11]$ & 0.115 \\
Distance to nearest waterway (km) & $4.64(2.93)$ & $4.72(2.98)$ & $4.58(2.90)$ & $0.95[0.90 ; 1.01]$ & 0.097 \\
Elevation & $188(7.06)$ & $188(7.00)$ & $188(7.11)$ & $0.94[0.89 ; 1.00]$ & 0.043 \\
\hline
\end{tabular}


Table 4 Full and reduced models of flooding using all sufficiently represented variables. Reduced model found through backwards selection through AIC. All continuous variables have been standardized and thus odds ratios for these variables represent changes in odds given unit changes in z-scores.

\begin{tabular}{|c|c|c|}
\hline & \multicolumn{2}{|c|}{ Dependent variable: } \\
\hline & \multicolumn{2}{|c|}{ Flooding } \\
\hline & $\begin{array}{l}\text { Full model } \\
\text { (1) }\end{array}$ & $\begin{array}{c}\text { Reduced model } \\
\text { (2) }\end{array}$ \\
\hline Census tract poverty & $1.111(0.966,1.255)$ & \\
\hline Census tract under 18 poverty & $0.927(0.809,1.045)$ & \\
\hline African-American population & $1.156^{* * *}(1.040,1.271)$ & $1.142^{* * *}(1.035,1.249)$ \\
\hline Distance to nearest waterway & $1.037(0.922,1.152)$ & \\
\hline Elevation & $0.975(0.857,1.093)$ & \\
\hline Percent of homes owner occupied & $0.909 * *(0.833,0.984)$ & $0.901^{* * *}(0.830,0.972)$ \\
\hline Percent of homes built before 1939 & $1.165^{* * *}(1.059,1.271)$ & $1.187^{* * *}(1.092,1.281)$ \\
\hline Rent home & $1.443^{* * *}(1.204,1.683)$ & $1.436^{* * *}(1.199,1.673)$ \\
\hline Mold on walls of basement & $1.945^{* * *}(1.477,2.413)$ & $1.943^{* * *}(1.476,2.410)$ \\
\hline Moldy smells & $1.314^{* *}(1.006,1.621)$ & $1.321^{* *}(1.012,1.630)$ \\
\hline Basement needs repair & $5.432^{* * *}(4.220,6.644)$ & $5.353^{* * *}(4.164,6.541)$ \\
\hline Roof leaks & $0.846(0.622,1.071)$ & \\
\hline Window leaks & $0.677^{* *}(0.420,0.934)$ & $0.643^{* *}(0.418,0.867)$ \\
\hline Chimney leaks & $1.177(0.506,1.848)$ & \\
\hline Plumbing leaks & $1.384^{* *}(0.955,1.813)$ & $1.393^{* *}(0.973,1.814)$ \\
\hline Foundation cracks & $1.374^{* *}(1.022,1.727)$ & $1.347^{* *}(1.018,1.677)$ \\
\hline Sinks and bathtub drain properly & $0.857^{*}(0.707,1.007)$ & $0.861^{*}(0.711,1.012)$ \\
\hline Uncapped sewer outlets & $1.295^{* * *}(1.071,1.520)$ & $1.282^{* * *}(1.061,1.504)$ \\
\hline Ever had sewer backups & $12.010^{* * *}(9.866,14.154)$ & $11.947^{* * *}(9.821,14.074)$ \\
\hline Gaps large enough for animals and insects & $1.061(0.851,1.271)$ & \\
\hline Constant & $0.016^{* * *}(0.006,0.025)$ & $0.018^{* * *}(0.010,0.026)$ \\
\hline Observations & 4,677 & 4,677 \\
\hline Log Likelihood & $-2,081.237$ & $-2,083.677$ \\
\hline Akaike Inf. Crit. & $4,204.474$ & $4,195.353$ \\
\hline
\end{tabular}


Table 5: Prevalence and determinants of asthma in at least one adult member of the household. Odds ratios for continuous measures from standardized values (z-scores).

\begin{tabular}{|c|c|c|c|c|}
\hline & $\begin{array}{c}\text { No } \\
N=1410\end{array}$ & $\begin{array}{c}\text { Yes } \\
\mathrm{N}=4154\end{array}$ & OR & p.ratio \\
\hline Experienced flooding & $564(49.2 \%)$ & $1898(55.8 \%)$ & $1.30[1.14 ; 1.49]$ & ¡0.001 \\
\hline Child in the home with asthma & $660(61.6 \%)$ & $2743(87.4 \%)$ & $4.30[3.66 ; 5.06]$ & 0.000 \\
\hline Breathing problems & $507(38.8 \%)$ & $3198(80.9 \%)$ & $6.70[5.84 ; 7.68]$ & 0.000 \\
\hline Smoker in the home & $681(49.4 \%)$ & $2424(60.0 \%)$ & $1.54[1.36 ; 1.74]$ & ¡0.001 \\
\hline \multicolumn{5}{|l|}{ Year house was built (categorical): } \\
\hline Pre 1910 & $196(19.3 \%)$ & $682(22.4 \%)$ & Ref. & Ref. \\
\hline $1910-1930$ & $420(41.4 \%)$ & $1216(39.9 \%)$ & $0.83[0.68 ; 1.01]$ & 0.062 \\
\hline $1931-1940$ & $110(10.8 \%)$ & $315(10.3 \%)$ & $0.82[0.63 ; 1.08]$ & 0.158 \\
\hline $1941-1945$ & $32(3.16 \%)$ & $98(3.22 \%)$ & $0.88[0.58 ; 1.37]$ & 0.556 \\
\hline 1946-1957 & $199(19.6 \%)$ & $546(17.9 \%)$ & $0.79[0.63 ; 0.99]$ & 0.041 \\
\hline 1958 or later & $57(5.62 \%)$ & $190(6.24 \%)$ & $0.96[0.69 ; 1.35]$ & 0.797 \\
\hline Roof in good condition & $259(25.9 \%)$ & $696(23.5 \%)$ & $0.88[0.74 ; 1.04]$ & 0.120 \\
\hline Mold on walls of basement & $784(70.4 \%)$ & $2486(75.8 \%)$ & $1.32[1.13 ; 1.53]$ & ¡0.001 \\
\hline Moldy smells & $751(67.4 \%)$ & $2416(73.3 \%)$ & $1.32[1.14 ; 1.53]$ & ¡0.001 \\
\hline Basement needs repair & $757(70.6 \%)$ & $2403(77.0 \%)$ & $1.40[1.19 ; 1.63]$ & ¡0.001 \\
\hline Roof leaks & $1073(83.6 \%)$ & $3189(85.1 \%)$ & $1.12[0.94 ; 1.33]$ & 0.206 \\
\hline Window leaks & $1177(91.7 \%)$ & $3503(93.5 \%)$ & $1.29[1.02 ; 1.64]$ & 0.036 \\
\hline Chimney leaks & $1243(96.9 \%)$ & $3666(97.8 \%)$ & $1.46[0.98 ; 2.13]$ & 0.060 \\
\hline Plumbing leaks & $1122(87.5 \%)$ & $3361(89.7 \%)$ & $1.25[1.03 ; 1.52]$ & 0.027 \\
\hline No leaks & $471(36.7 \%)$ & $1221(32.6 \%)$ & $0.83[0.73 ; 0.95]$ & 0.007 \\
\hline Foundation cracks & $976(83.3 \%)$ & $2940(84.6 \%)$ & $1.10[0.92 ; 1.32]$ & 0.281 \\
\hline Sinks and bathtub drain properly & $372(27.4 \%)$ & $1062(26.6 \%)$ & $0.96[0.84 ; 1.10]$ & 0.563 \\
\hline Uncapped sewer outlets & $803(67.9 \%)$ & $2502(71.0 \%)$ & $1.16[1.01 ; 1.34]$ & 0.042 \\
\hline Ever had sewer backups & $715(63.6 \%)$ & $2249(67.6 \%)$ & $1.20[1.04 ; 1.38]$ & 0.014 \\
\hline Gaps large enough for animals and insects & $877(71.0 \%)$ & $2745(76.0 \%)$ & $1.30[1.13 ; 1.50]$ & ¡0.001 \\
\hline Census tract poverty (\%) & $43.2(11.6)$ & $43.5(11.5)$ & $0.94[0.88 ; 1.00]^{*}$ & 0.048 \\
\hline Census tract under 18 poverty (\%) & $59.2(17.6)$ & $59.5(17.4)$ & $1.02[0.96 ; 1.08]$ & 0.487 \\
\hline African-American population (\%) & $0.81(0.30)$ & $0.79(0.31)$ & $0.94[0.88 ; 1.00]$ & 0.048 \\
\hline Distance to nearest waterway & $4.74(3.10)$ & $4.55(2.98)$ & $0.94[0.89 ; 1.00]$ & 0.041 \\
\hline Elevation & $188(7.13)$ & $188(7.08)$ & $0.95[0.89 ; 1.00]^{*}$ & 0.069 \\
\hline Percent of homes owner occupied & $0.51(0.13)$ & $0.50(0.14)$ & $0.98[0.92 ; 1.04]$ & 0.486 \\
\hline Percent of home built before 1939 & $0.42(0.24)$ & $0.43(0.24)$ & $1.00[0.94 ; 1.07]$ & 0.899 \\
\hline
\end{tabular}


CUS data: Household flooding events

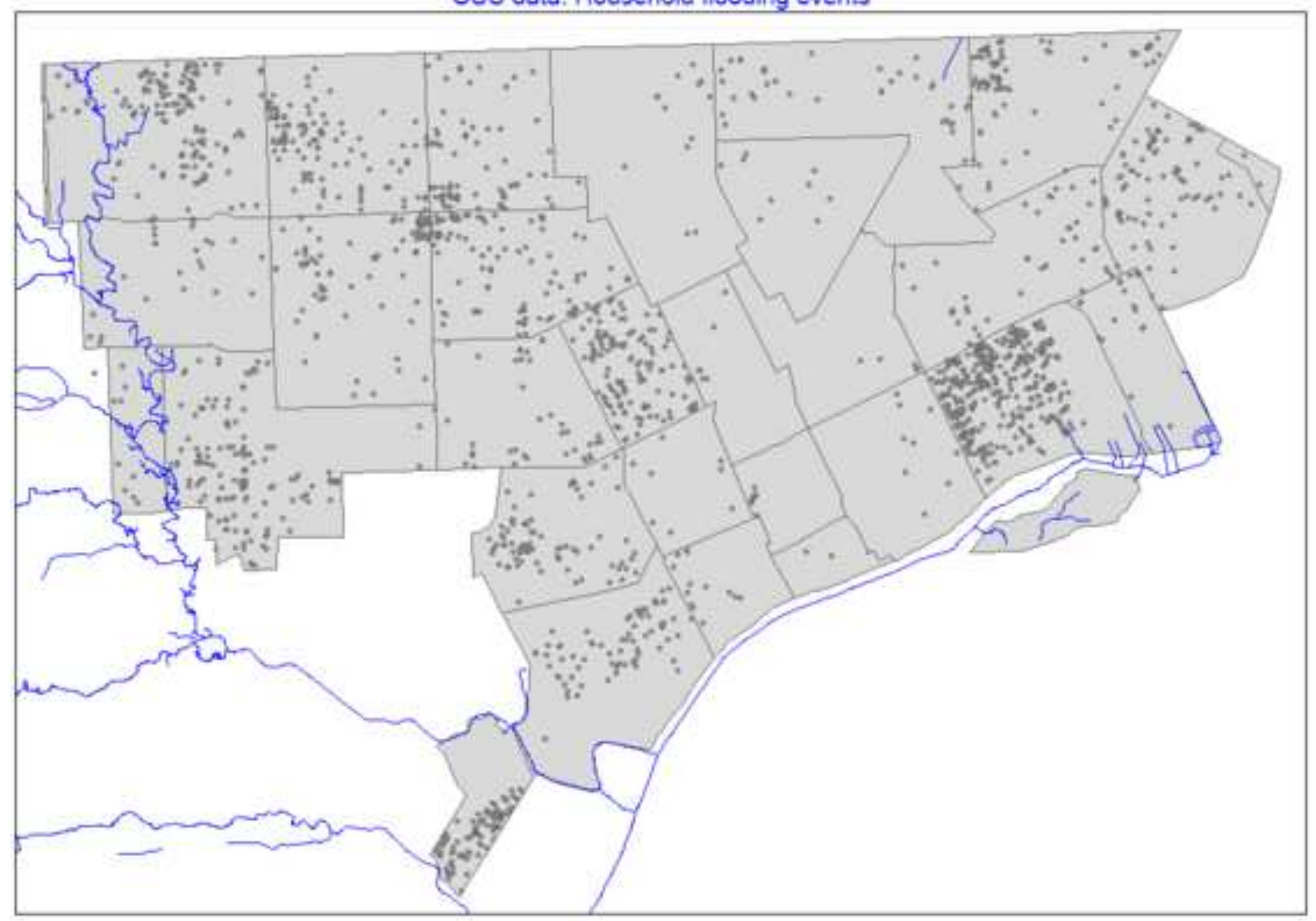




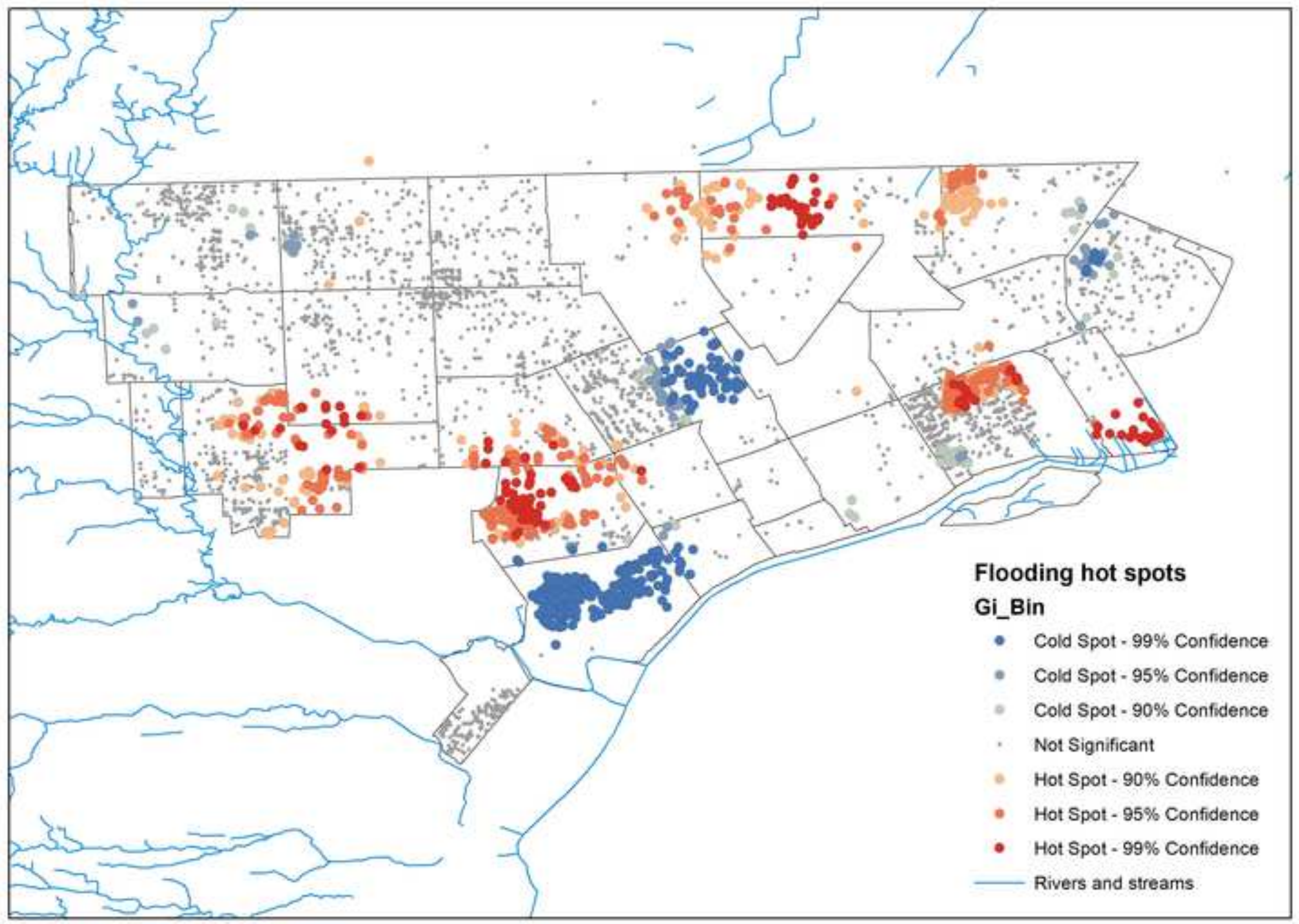




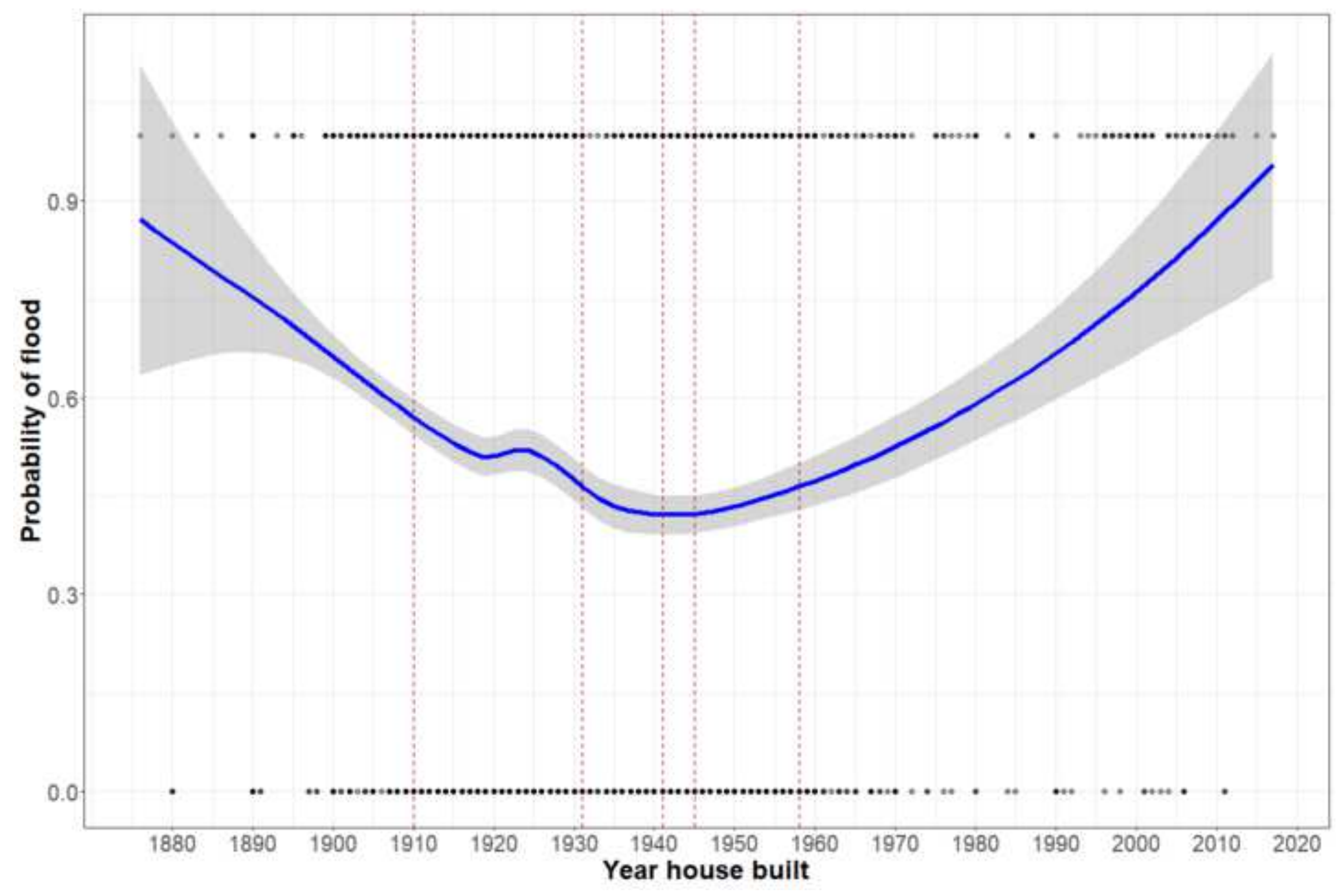




\section{Figures}

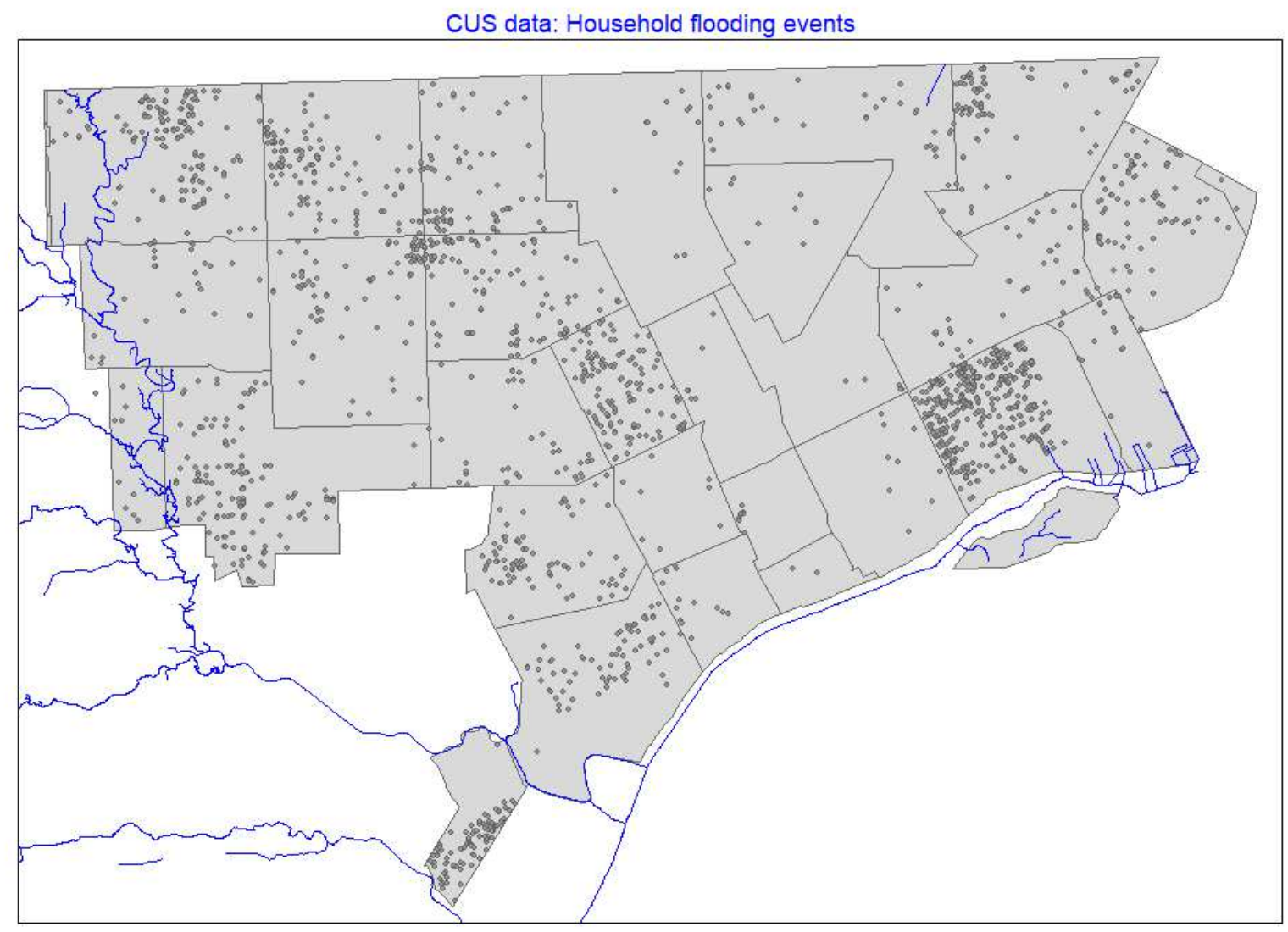

\section{Figure 1}

Locations of households which reported that they experienced pluvial flooding. Households that responded that no flooding occurred are not shown. Note: The designations employed and the presentation of the material on this map do not imply the expression of any opinion whatsoever on the part of Research Square concerning the legal status of any country, territory, city or area or of its authorities, or concerning the delimitation of its frontiers or boundaries. This map has been provided by the authors. 


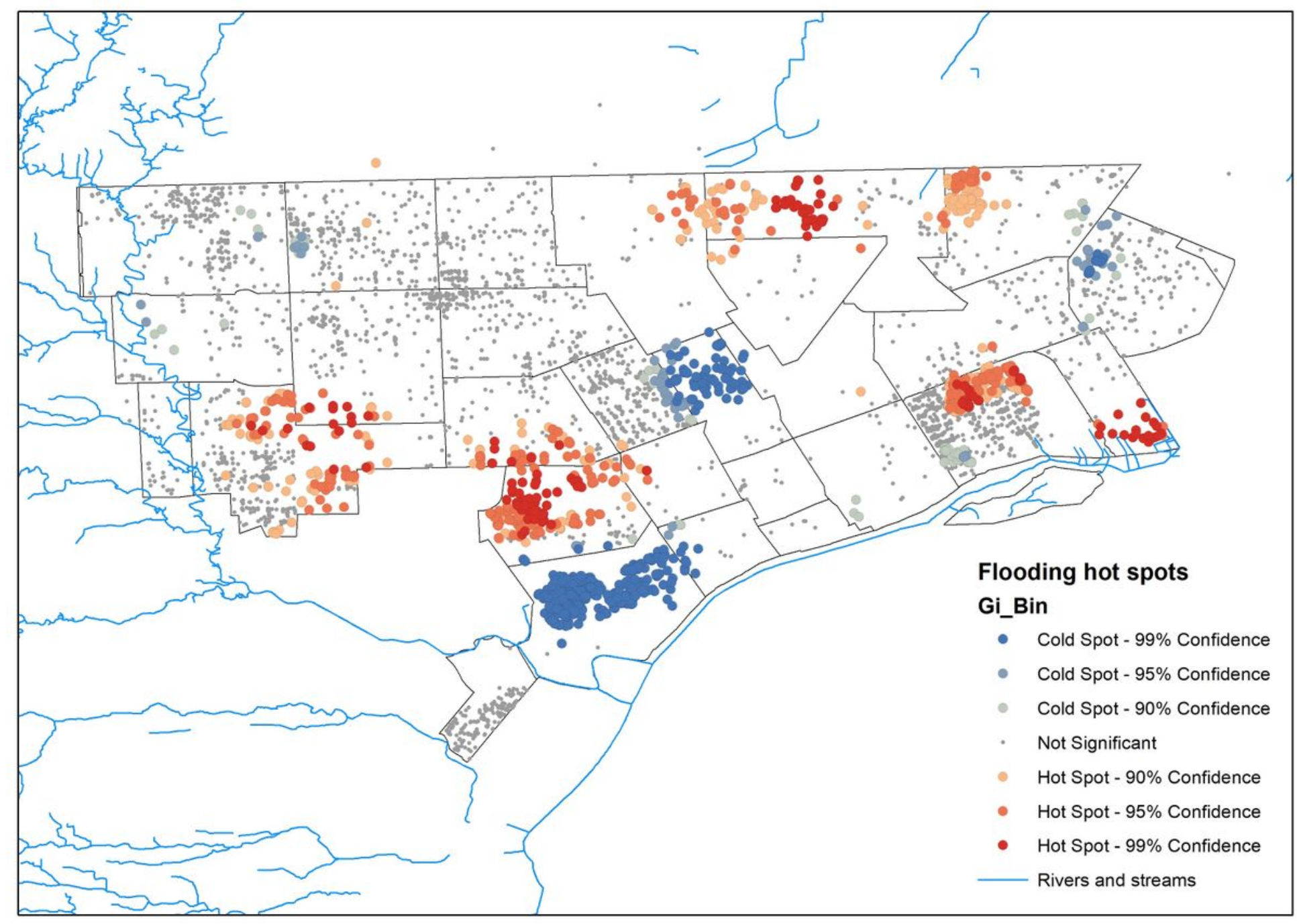

Figure 2

Hot and cold spots of flooding using the Getis-Ord Gi* statistic. Red dots represent "hot" spots, or locations of statistically significant clusters of homes that experienced flooding. Blue does represent clusters of homes that reported not experiencing flooding. Note: The designations employed and the presentation of the material on this map do not imply the expression of any opinion whatsoever on the part of Research Square concerning the legal status of any country, territory, city or area or of its authorities, or concerning the delimitation of its frontiers or boundaries. This map has been provided by the authors. 


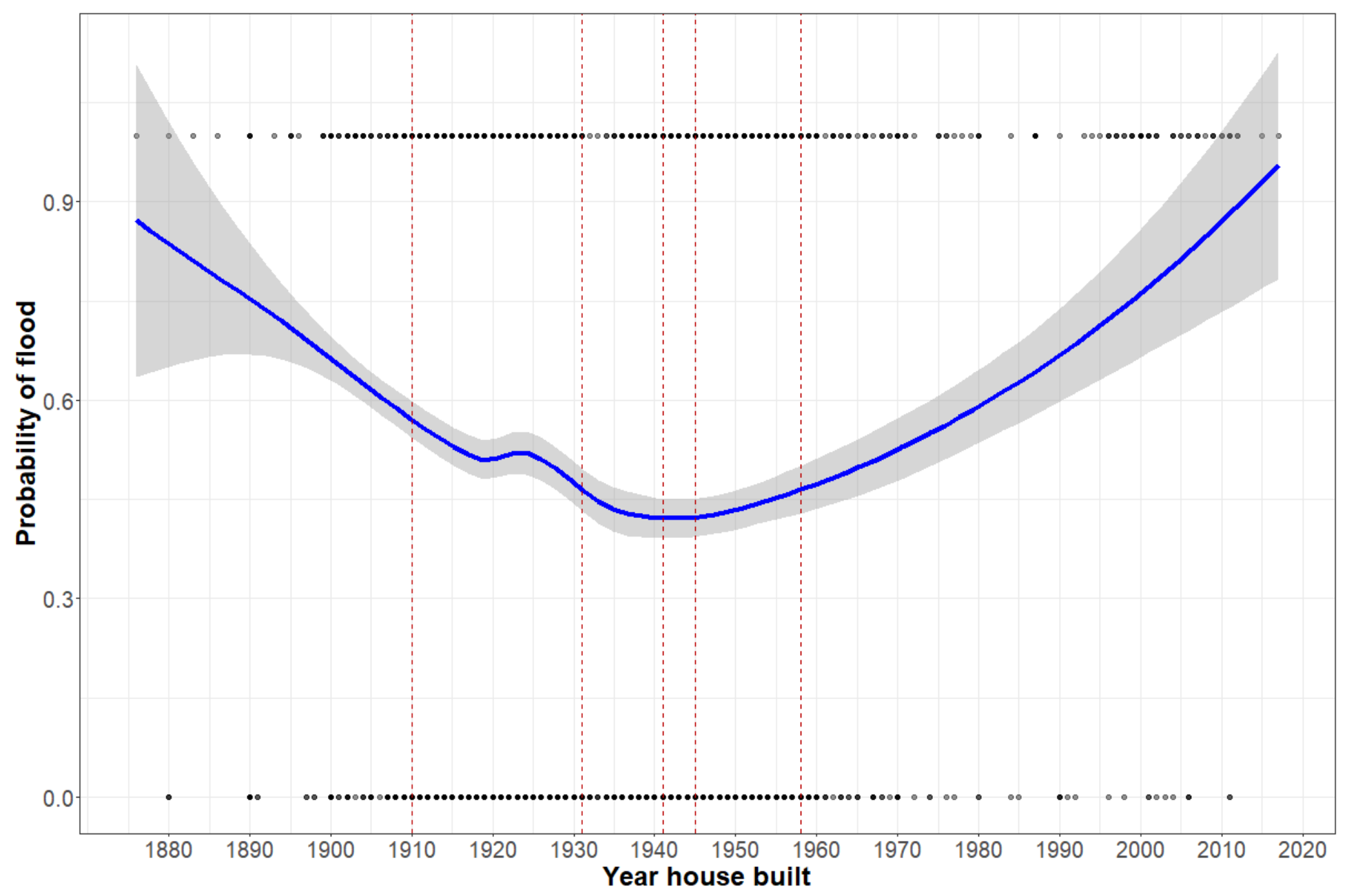

Figure 3

Estimated flooding risk by year of construction using LOESS interpolation method. Vertical lines represent successive building waves (1870 - 1910, 1911 - 1930, etc.) used to create housing construction categories 